Vol. 4: 419-427.

\title{
Effect of seed dressing treatment of Streptomyces griseoviridis on barley and spring wheat in field experiments
}

\author{
Risto Tahvonen, Asko Hannukkala and Hanna Avikainen \\ Agricultural Research Centre of Finland, Institute of Plant Protection, FIN-31600 Jokioinen, Finland
}

\begin{abstract}
The effect of seed dressing with the antagonist Streptomyces griseoviridis on root rots and yields of wheat and barley was studied in field experiments. In long-term field experiments, where different levels of soil-borne inoculum of root rots were maintained with different crop sequences, seed treatment with the antagonist increased yields slightly on average over all experimental years. However, variations between years, crops and crop sequences were considerable. The highest yield increases were in excess of $600 \mathrm{~kg} / \mathrm{ha}$, whilst treatment occasionally resulted in slight yield losses. In experiments in which seed naturally infested with Fusarium spp. was used, seed treatment with S. griseoviridis increased yields of wheat but not those of barley. Seed dressing with an organomercurial fungicide resulted in higher yield increases than the biopreparate.
\end{abstract}

Key words: biological control, Bipolaris sorokiniana, Fusarium spp., Gaeumannomyces graminis, Mycostop, crop rotation,

Foot and root rot diseases are a world wide problem in intensive cereal crop production. In Finland common root rot (Fusarium avenaceum (Corda ex Fr.) Sacc., F. culmorum (W. G. Sm.) Sacc., Bipolaris sorokiniana (Sacc.) Shoem.) and take-all (Gaeumannomyces graminis (Sacc.) v. Arx \& Olivier) are widespread throughout the cereal growing area (Mäkelä and Parikka 1980).

Yield losses caused by common root rot may exceed up to 10\% (Uoti 1976, Kurppa 1985). The damage is most severe in cereal monoculture. Dry growing seasons favour infection by Fusarium species (Wiese 1987). Take-all is extremely damaging in cereal monoculture on light soils during wet seasons, when $90 \%$ crop losses have been reported (Yarham 1981).

Common root rot fungi are seed- and soilborne. Seed-borne inoculum can be controlled by chemical seed dressing (Uoti 1979, Kurppa 1985 , Wiese 1987). There is, however, no effective chemical control against soil-borne inoculum of common root rot and truly soil-borne take-all. Soil-borne root rots are mainly controlled by diverse crop rotations and other cultural practices (Yarham 1981, Wiese 1987).

Much effort has gone into investigation of the biocontrol of soil-borne root-rots of cereals. Numerous soil-inhabiting micro-organisms, e.g. 


\section{AGRICULTURAL SCIENCE IN FINLAND}

Tahvonen R. et al.: Effect of seed dressing treatment of streptomyces griseoviridis...

Trichoderma and Gliocladium fungi and Streptomyces bacteria, have been shown to prevent growth of root rot pathogens on agar and to suppress disease severity in bioassays and field trials (Domsch and Gams 1968, Uoti 1976, Harman and Taylor 1990). Root inhabiting fluorescent Pseudomonas bacteria have demostrated great potential in the control of take-all (Bowen and Rovira 1976, Weller and Cook 1983, Ryder et al. 1990).

Seed dressing with spores or mycelia of the antagonist has proved to be a reliable way of controlling a number of diseases (Mangenot and Diem 1979, Papavizas and Lewis 1980). The antagonist applied to seeds protects them from infection and may also colonize the rhizosphere. The activity of the antagonist can be intensifed by different additives, e.g. nutrients (Harman and Taylor 1990).

Streptomyces griseoviridis Anderson et al. has been successfully used for controlling seedborne diseases of cruciferous plants (Tahvonen and Avikainen 1987) and numerous soil-borne diseases (Tahvonen 1982, 1988). Preliminary studies of Tahvonen and Avikainen (1990) indicated that the antagonist also has potential for controlling common root, Fusarium spp. and B. sorokiniana, of cereals. This study investigates the efficacy of $S$. griseoviridis seed dressing on barley and spring wheat against foot rot diseases in field conditions and its effect on spring wheat and barley yields.

\section{Material and methods}

\section{Crop-rotation experiments}

The performance of the antagonist Streptomyces griseoviridis in the field was studied in two crop-rotation experiments, with rotations maintaining different levels of soil-borne inoculum of root-rot pathogens, Fusarium spp., Gaeumannomyces graminis and $B$. sorokiniana.

The five year crop rotation experiment conducted at Helsinki (Viikki) in 1982-86 consist- ed of four crop sequence types containing $100 \%$, $75 \%, 50 \%$ or $25 \%$ wheat (cv. Ruso) or barley (cv. Kustaa). Both barley and wheat were grown in monoculture $(100 \%)$, which was interrupted every three years with fallow $(75 \%)$, barley and wheat were exchanged every other year for oats, turnip rape and field bean (50\%) and barley and wheat were grown in-four year rotation with oats, turnip rape and field bean $(25 \%)$ (Hannukkala 1985). At Jokioinen, a four-year barley (cv. Pokko) and wheat (cv. Luja) monoculture together with barley and wheat grown in one, two and three consecutive years after grass ley maintained three, two and one years, respectively were included in the crop rotation experiment in 198587.

Both experiments consisted of two sub-trials, one with barley and the other with wheat as the test crop. The experimental design was a split-plot model with four replications. Crop sequences were placed in the main plots and the seed treatments in subplots. Plot size at Helsinki was $8 \mathrm{~m}^{2}$ and at Jokioinen $10 \mathrm{~m}^{2}$.

\section{Seed dressing experiments}

The effect of $S$. griseoviridis on seed-borne rootrot diseases was studied in 1984-86. A set of field experiments using artificially infected seed was carried out at three locations, Jokioinen, Kotkaniemi and Mietoinen, in 1984-85. Two barley seed lots (cv. Pokko) were inoculated by soaking in aquaceous suspension of two pathogens, Fusarium culmorum and B. sorokiniana as described by Tahvonen and Avikainen (1990). Seed lots heavily contaminated with common root rot pathogens were screened in pot experiments in 1986 (Tahvonen and Avikainen 1990). Four seed lots of barley (cvs. Arra, Etu, Pokko and Potra) and three seed lots of wheat (cvs. Luja and Tapio) were selected for the field test. A split-plot experimental design with four replications, where the main plots were infected seed lots and the sub-plots were seed dressings, was used in both sets of experiments. The plot size was $10 \mathrm{~m}^{2}$. 


\section{AGRICULTURAL SCIENCE IN FINLAND}

Vol. 4: 419-427.

\section{Biocontrol agent and seed treatments}

The $S$. griseoviridis used as a biocontrol agent in all studies was originally isolated from Finnish peat (Tahvonen 1982). In 1982-84 the seed was treated with the spore suspension of the antagonist in sterile water as described by Tahvonen (1982). In 1985-87 the seed was treated with a powdery product, "Mycostop" Kemira Oy, Finland, containing mycelium and spores of $\mathrm{S}$. griseoviridis at minimum of $10^{8} \mathrm{cfu}$ per $\mathrm{g}$ (Tahvonen and Avikainen 1987).

Mycostop was applied to seeds by shaking them with the powdery product in the same manner as standard fungicides. The standard dose was $3 \mathrm{~g}$ Mycostop $/ \mathrm{kg}$ seed. An additional dose of $10 \mathrm{~g} \mathrm{Mycostop} / \mathrm{kg}$ seed was included in the crop rotation experiment at Jokioinen and the experiment with naturally infested seed. An untreated control was included in all experiments. Standard organomercury treatment (Täyssato, Kemira Oy or Ceresan, Berner Oy (metoxyethylmercurychloride a.i.) $2 \mathrm{~g} / \mathrm{kg}$ seed) was used in all experiments except the crop-rotation experiment at Helsinki.

\section{Other trial methods and analyses}

The soil type in all experiments was heavy clay with the exception of those at Kotkaniemi, where it was fine sand. Soil acidity ranged from $\mathrm{pH} 5.5$ to 6.5 . Trials received $80 \mathrm{~kg} \mathrm{~N} / \mathrm{ha}$ in the form of compound fertilizer. The type of fertilizer chosen depended on the nutritional status of each individual experimental field. Commercial herbicides were used for weed control, depending on the dominant weed population in the field.

Growing seasons during the study were extremely variable. Sowing dates varied from the last week of April to the third week of May and harvesting dates from the fourth week of August to the third week of September. The beginning of the growing season in 1982 and 1985 was exceptionally cool and moist. In 1983, 1984 and 1986 the spring was warm and, especially in
1984 , very dry. The 1987 Growing season was one of the coldest this century .

The stem bases of the plants were rated for disease at growth stage 20-30 (Zadoks et al. 1974) from a sample of $25-50$ plants/plot. At Helsinki an additional sample was taken at growth stage 75 and both stem bases and roots were rated for the disease. The disease data were studied by the loglinear modelling available in the SAS CATMOD procedure. For modelling the original disease ratings were grouped into three symptom classes (healthy, moderate and severe). Disease ratings are not presented in the results, because there were no statistically significant differences between treatments.

The yield data were analysed by modifications of the analysis of variance according to each experimental design using the SAS GLM procedure. Before the analyses of variance the data were studied by the SAS UNIVARIATE procedure to confirm that the data fulfilled the assumptions of analysis of variance. No transformations were needed for the data. The data were further studied by the Tukey HSD test. Statistical significances are expressed by asterixes (***, $\mathrm{P}<0.001$; **, $\mathrm{P}<0.01$;, $\mathrm{P}<0.05$; NS, $\mathrm{P}>0.05)$ and/or using different letters to show individual means belonging to the different group at the $0.05 \%$ significance level.

\section{Results and discussion}

Seed treatment with $S$. griseoviridis suspension increased yields considerably in the crop rotation experiment at Viikki in 1982. The maximum yield increase in barley was about $640 \mathrm{~kg} / \mathrm{ha}$ and in wheat $310 \mathrm{~kg} / \mathrm{ha}$. The high yield increases encouraged us to continue testing and to start new field studies. The following years however, showed that neither the suspension nor the powdery product of the antagonist could provide any consistent positive effect on yield. On average over years and crop sequences, the antagonist increased barley yilds slightly but caused minor losses to wheat yields (Table 1). 


\section{AGRICULTURAL SCIENCE IN FINLAND}

Tahvonen R. et al.: Effect of seed dressing treatment of streptomyces griseoviridis...

Table 1. Effect of Streptomyces seed treatment on wheat and barley yields in a five year crop rotation experiment at Viikki in 1982-86.

\begin{tabular}{|c|c|c|c|c|c|c|c|}
\hline \multirow[b]{2}{*}{ Crop sequence } & \multicolumn{6}{|c|}{ Yield increase/decrease $\mathrm{kg} / \mathrm{ha}$} & \multirow{2}{*}{$\begin{array}{c}\text { Mean yield } \\
\text { of untreated } \\
\text { control }\end{array}$} \\
\hline & 1982 & 1983 & 1984 & 1985 & 1986 & mean & \\
\hline \multicolumn{8}{|c|}{ Wheat } \\
\hline Monoculture & 311 & -146 & 58 & -110 & 85 & 40 & 3650 \\
\hline $75 \%$ wheat & 117 & -223 & -130 & -85 & -56 & -75 & 4108 \\
\hline $50 \%$ wheat & -88 & -298 & 15 & 5 & -146 & -102 & 4155 \\
\hline $25 \%$ wheat & -383 & -110 & -70 & 9 & -13 & -113 & 4017 \\
\hline $\begin{array}{l}\text { Mean yield of } \\
\text { untreated seed }\end{array}$ & 4831 & 5021 & 5066 & 2417 & 2949 & & \\
\hline
\end{tabular}

\begin{tabular}{lrrrrrrr} 
& \multicolumn{7}{c}{ Barley } \\
Monoculture & 289 & 37 & 174 & -61 & -264 & 35 & 4358 \\
$75 \%$ barley & 638 & -102 & 83 & -64 & -219 & 68 & 4384 \\
$50 \%$ barley & 328 & 234 & 11 & 124 & 12 & 142 & 4435 \\
$25 \%$ barley & 481 & -180 & -6 & -174 & -92 & 6 & 4745 \\
\hline $\begin{array}{l}\text { Mean yield of } \\
\text { untreated seed }\end{array}$ & 4889 & 5703 & 5145 & 3397 & 3090 & & \\
\hline
\end{tabular}

F-values:

Crop sequence (Cs)
Year $(\mathrm{Y})$
Treatment $(\mathrm{T})$
Y x Cs
Y x T
Cs x T

$\begin{array}{cc}\text { Wheat } & \text { Barley } \\ 14.73^{* * *} & 16.41^{* * *} \\ 1354.61^{* * *} & 848.25^{* * *} \\ 10.97^{* *} & 10.24^{* *} \\ 10.58^{* *} & 6.17^{* *} \\ 1.66 \mathrm{NS} & 7.21^{* *} \\ 1.12 \mathrm{NS} & 1.85 \mathrm{NS}\end{array}$

In the crop rotation experiment at Jokioinen, none of the seed treatments had a statistically significant effect on barley yields. Ley as the precrop decreased yields in 1986 and 1987 (Table 2). There were however, no statistically significant differences in visible stem base symptoms between seed treatments or between crop sequences.

In wheat all seed treatments increased yields as compared with the untreated control. Mercury treatment always gave higher yield increases than Streptomyces-treatment. Ley as a precrop decreased wheat yields each experimental year. The highest yield increases due to seed treatments were obtained after ley as the precrop (Table 3). No statistically significant differences in visible stem base symptoms were detected between seed treatments or crop sequences.
The yield decrease after ley was probably caused by a biotic factor, which could be controlled to some extent by seed treatments. Ley probably increased the inoculum of some 'minor' pathogens (Salt 1979) e.g. snow mould, Microdochium nivale (Ces. ex Berl. \& Vogl.) Samuels \& Hallet, an agent that typically kills grasses in winter, may cause mild symptoms in both barley and wheat (Wiese 1987).

The variations in the effects of seed treatments between years and experiments indicate that establishment of the antagonist is higly dependent on environmental factors, e.g. soil moisture and temperature, as was also stressed by Bowen and Rovira (1976), Papavizas and Lewis (1980) and Harman and Taylor (1990). The yield increases obtained with seed treatment despite insignificant differences in disease ratings may 
Vol. 4: 419-427.

Table 2. Effect of Streptomyces and mercury seed treatment on barley yields in a four year crop rotation experiment at Jokioinen in 1985-87.

\begin{tabular}{|c|c|c|c|c|c|c|c|c|}
\hline \multirow{3}{*}{ Year } & \multirow{3}{*}{ Precrop } & \multirow{3}{*}{$\begin{array}{l}\text { Untreated } \\
\text { control } \\
\mathrm{kg} / \mathrm{ha}\end{array}$} & \multicolumn{3}{|c|}{ Increase/decrease $\mathrm{kg} / \mathrm{ha}$} & \multirow[b]{3}{*}{$\begin{array}{l}\text { Mean } \\
\mathrm{kg} / \mathrm{ha}\end{array}$} & & \multirow[b]{3}{*}{ F value } \\
\hline & & & \multicolumn{2}{|c|}{ Streptomyces } & \multirow[t]{2}{*}{ Mercury } & & & \\
\hline & & & $3 \mathrm{~g} / \mathrm{kg}$ & $10 \mathrm{~g} / \mathrm{kg}$ & & & & \\
\hline \multicolumn{9}{|l|}{1985} \\
\hline & ley & 4427 & 35 & 19 & 256 & 4505 & A & \multirow{3}{*}{$\begin{array}{l}\text { precrop } 2.53 \\
\text { seed tr. } 0.69 \\
\text { prec. x seed. } 0.80\end{array}$} \\
\hline & barley & 4643 & 67 & 39 & 19 & 4674 & A & \\
\hline & mean & 4535 a & 51 a & 29 a & $138 \mathrm{a}$ & 4589 & A & \\
\hline \multicolumn{9}{|l|}{1986} \\
\hline & ley + ley & 3430 & 40 & 63 & 50 & 3468 & A & \multirow{4}{*}{$\begin{array}{l}\text { precrop } 9.36^{*} \\
\text { seed tr. } 1.27 \\
\text { prec. x seed. } 0.27\end{array}$} \\
\hline & barley + ley & 3177 & 126 & 126 & 313 & 3318 & A & \\
\hline & barley + barley & 3958 & 129 & 56 & 186 & 4051 & B & \\
\hline & mean & $3522 \mathrm{a}$ & 98 a & $82 \mathrm{a}$ & $183 \mathrm{a}$ & 3612 & & \\
\hline \multicolumn{9}{|l|}{1987} \\
\hline & ley + ley + ley & 3048 & 244 & -168 & 174 & 3111 & $\mathrm{AB}$ & \multirow{5}{*}{$\begin{array}{l}\text { precrop } 3.92^{*} \\
\text { seed tr. } 0.18 \\
\text { prec. x seed. } 1.92\end{array}$} \\
\hline & barley + ley + ley & 3306 & -521 & -50 & -293 & 3091 & $\mathrm{AB}$ & \\
\hline & barley + barley + ley & 2398 & 238 & -78 & 248 & 2500 & A & \\
\hline & barley + barley + barley & 3266 & 100 & 163 & 30 & 3340 & B & \\
\hline & mean & $3005 \mathrm{a}$ & $15 \mathrm{a}$ & $-33 \mathrm{a}$ & $40 \mathrm{a}$ & 3010 & & \\
\hline
\end{tabular}

Table 3. Effect of Streptomyces seed and mercury treatment on spring wheat yield in a four-year crop rotation experiment at Jokioinen in 1985-87.

\begin{tabular}{|c|c|c|c|c|c|c|c|}
\hline \multirow{3}{*}{ Year } & \multirow{3}{*}{ Precrop } & \multirow{3}{*}{$\begin{array}{l}\text { Untreated } \\
\text { control } \\
\mathrm{kg} / \mathrm{ha}\end{array}$} & \multicolumn{3}{|c|}{ Increase/decrease $\mathrm{kg} / \mathrm{ha}$} & & \multirow[b]{3}{*}{ F value } \\
\hline & & & Strep & yces & Mercury & \multirow[b]{2}{*}{$\begin{array}{c}\text { Mean } \\
\text { yield kg/ha }\end{array}$} & \\
\hline & & & $3 \mathrm{~g} / \mathrm{kg}$ & $10 \mathrm{~g} / \mathrm{kg}$ & & & \\
\hline \multicolumn{8}{|l|}{1985} \\
\hline & ley & 3466 & 528 & 342 & 860 & $3899 \mathrm{~A}$ & \multirow{3}{*}{$\begin{array}{l}\text { precrop } 17.26^{* *} \\
\text { seed tr. } 30.99 * * * \\
\text { prec. } x \text { seed. } 1.54\end{array}$} \\
\hline & wheat & 3986 & 433 & 437 & 632 & $4362 \mathrm{~B}$ & \\
\hline & mean & 3726 a & $480 \mathrm{~b}$ & $390 \mathrm{~b}$ & $746 c$ & & \\
\hline \multicolumn{8}{|l|}{1986} \\
\hline & ley + ley & 2714 & 80 & 219 & 423 & $2894 \mathrm{~A}$ & \multirow{4}{*}{$\begin{array}{l}\text { precrop } 14.82^{* * *} \\
\text { seed } \operatorname{tr} 18.97^{* * *} \\
\text { prec. } x \text { seed. } 0.50\end{array}$} \\
\hline & wheat + ley & 2682 & 66 & 149 & 439 & $2845 \mathrm{~A}$ & \\
\hline & wheat + wheat & 3150 & 35 & -4 & 352 & 3245 B & \\
\hline & mean & 2848 a & $61 \mathrm{a}$ & $121 \mathrm{a}$ & $405 \mathrm{~b}$ & 2995 & \\
\hline \multicolumn{8}{|l|}{1987} \\
\hline & ley + ley + ley & 1670 & 416 & 475 & 546 & 2029 A & \multirow{5}{*}{$\begin{array}{l}\text { precrop } 14.36 * * * \\
\text { seed tr. } 0.70 \\
\text { prec. } x \text { seed. } 1.71\end{array}$} \\
\hline & wheat + ley + ley & 2365 & 119 & 50 & -39 & $2398 \mathrm{AB}$ & \\
\hline & wheat + wheat + ley & 2503 & 106 & -115 & 171 & 2543 B & \\
\hline & wheat + wheat + wheat & 3218 & -163 & -1 & -278 & $3108 \mathrm{C}$ & \\
\hline & mean & 2439 a & $119 \mathrm{a}$ & $102 \mathrm{a}$ & $100 \mathrm{a}$ & 2519 & \\
\hline
\end{tabular}


Tahvonen R. et al.: Effect of seed dressing treatment of streptomyces griseoviridis...

Table 4. Effect of Streptomyces and mercury treatment of uninoculated seeds(I) or of barley seeds inoculated with Fusarium culmorum (II) or Bipolaris sorokiniana (III) on yield at three different experimental places.

\begin{tabular}{|c|c|c|c|c|c|}
\hline \multirow[b]{2}{*}{ Location } & \multirow[b]{2}{*}{ Seed treatment } & \multicolumn{4}{|c|}{ Yield and yield increase/decrease $\mathrm{kg} / \mathrm{ha}$} \\
\hline & & I & II & II & Mean \\
\hline & & \multicolumn{4}{|c|}{1984} \\
\hline \multirow[t]{3}{*}{ Jokioinen } & Untreated & 5611 & 5689 & 5639 & 5646 \\
\hline & Streptomyces & -192 & -213 & -159 & -188 \\
\hline & Mercury & -17 & -17 & -106 & -50 \\
\hline \multirow[t]{3}{*}{ Kotkaniemi } & Untreated & 2528 & 2378 & 2911 & 2606 \\
\hline & Streptomyces & +230 & +314 & +198 & +247 \\
\hline & Mercury & +234 & +295 & +31 & +187 \\
\hline \multirow[t]{4}{*}{ Mietoinen } & Untreated & 4660 & 4710 & 4710 & 4693 \\
\hline & Streptomyces & -120 & +130 & +10 & +7 \\
\hline & Mercury & +90 & +30 & +130 & +83 \\
\hline & & \multicolumn{4}{|c|}{1985} \\
\hline \multirow[t]{3}{*}{ Jokioinen } & Untreated & 6232 & 6519 & 6209 & 6320 \\
\hline & Streptomyces & -52 & -310 & +301 & -20 \\
\hline & Mercury & +95 & +195 & +606 & +299 \\
\hline \multirow[t]{3}{*}{ Kotkaniemi } & Untreated & 6492 & 6193 & 6100 & 6262 \\
\hline & Streptomyces & -383 & +177 & -33 & -80 \\
\hline & Mercury & +3 & +185 & +422 & 203 \\
\hline \multirow[t]{3}{*}{ Mietoinen } & Untreated & 4560 & 4330 & 4460 & 4450 \\
\hline & Streptomyces & -100 & +200 & +140 & +80 \\
\hline & Mercury & +150 & +230 & +160 & +180 \\
\hline \multirow[t]{3}{*}{ Mean } & Untreated & 5013 & 4970 & 5005 & 4996 \\
\hline & Streptomyces & -71 & +3 & +145 & +25 \\
\hline & Mercury & +93 & +153 & +207 & +151 \\
\hline
\end{tabular}

F values: No significant differences between treatments

be due to the ability of the antagonist to stimulate plant growth. Numerous soil and rhizosphere bacteria are known to stimulate crop growth (Gerhardson et al. 1985). Certain Actinomycetes belonging to the genus Streptomyces have been reported to promote wheat growth (El-Shanshoury 1989).

In experiments with artifically infested seed, inoculation with $F$. culmorum or B. sorokiniana caused little increase in disease incidence or decrease in yields as had been the case in preliminary pot experiments (Tahvonen and Avikainen 1990). Seed dressings with mercury or Streptomyces had no statistically significant effects on yields, though both treatments caused slight yield increases on average in all experiments (Table 4).
In 1986, when naturally infested seed was used in the experiments, treatment with Mycostop increased wheat yields by $130 \mathrm{~kg} / \mathrm{ha}$ and with the organomercurial compound by $580 \mathrm{~kg} /$ ha. Seed treatments had no statistically significant effects on barley yields (Table 5). Fusari$u m$ is known to be more destructive to wheat than barley, and healthy barley plants in the stand have a high capacity to compensate for the negative effects of diseased plants by more vigorous growth (Wiese 1987). These results indicate that seed treatment with either fungicide or biopesticide is more important in wheat than in barley for the control of common rot caused by Fusarium spp. The studies of Kurppa (1985) have shown that fungicides can significantly reduce 
Vol. 4: 419-427.

Table 5. Effect of seed treatment with Streptomyces and mercury on yield of four barley seed lots and six wheat seed lots in 1986 at Jokioinen.

\begin{tabular}{lrrrr}
\hline Treatment & \multicolumn{2}{c}{ Wheat } & \multicolumn{2}{c}{ Barley } \\
& Yield kg/ha & Range & Yield kg/ha & \multicolumn{1}{c}{ Range } \\
\hline Untreated & $4177 \mathrm{a}$ & $3705-4446$ & $4347 \mathrm{a}$ & $2903-5291$ \\
Mycostop 3g/kg & $+134 \mathrm{~b}$ & $+12-+267$ & $+10 \mathrm{a}$ & $-355-+234$ \\
Mycostop $10 \mathrm{~g} / \mathrm{kg}$ & $+129 \mathrm{~b}$ & $+32-+224$ & $+47 \mathrm{a}$ & $-116-+193$ \\
Mercury & $+577 \mathrm{c}$ & $+383-+925$ & $-44 \mathrm{a}$ & $-247-+149$ \\
\hline
\end{tabular}

Different letters show individual means belonging to the different group at the $0.05 \%$ significance level.

seed surface infection by B. sorokiniana but that they do not provide reliable control when seed is heavily infested.

Some antagonists have potential in the biological control of root rots of cereals. S. griseoviridis was originally isolated from peat, and the biopreparate Mycostop was developed to control diseases of greenhouse crops grown in a controlled environment (Tahvonen and Avikainen 1987, Lahdenperä 1987, 1992). S. griseoviridis has shown potential to control eyespot disease of cereals (Clarkson and Lucas 1993) and ear blight of wheat caused by Fusarium spp. (Lahdenperä et al. 1992). To control truly soilborne diseases in heavy clay soils in a cool cli- mate it is essential to look for microbes adapted to the soil environment where they will actually be used.

In conclusion, wheat yields can be increased by seed dressings more efficiently than can barley yields. Both fungicides and biopesticides can also affect soil-borne infection when the infection pressure is low. The $S$. griseoviridis preparate gave some protection against common root rot and was able to increase yields. However, chemical control with an organomercurial compound resulted in yield increases two to three times higher than those with the biopreparate tested.

\section{References}

Bowen, G. D. \& Rovira, A. D. 1976. Microbial colonization of plant roots. Annual Review of Phytopathology 14: 121-144.

Clarkson, J. P. \& Lucas, J. A. 1993. Screening for potential antagonists of Pseudocercosporella herpotrichoides, the causal agent of eyespot disease of cereals 1. Bacteria. Plant Pathology 42: 543-551.

Domsch, K. H. \& Gams, W. 1968. Die Bedeutung vorfruchtabhăngiger Verschiebungen in der Bodenmikroflora. I. Der Einfluss von Bodenpilzen zum Wurzelentwicklung von Weizen, Erbsen und Raps. Phytopathologische Zeitschrift 63: 64-74.

El-Shanshoury, A. R. 1989. Growth promotion of wheat seedlings by Streptomyces atroolivaceus. Journal of Agronomy and Crop Science 163: 109-114.

Gerhardson, B., Alström, S. \& Rämert, B. 1985. Plant reactions to inoculation of roots with fungi and bacteria. Phytopathologische Zeitschrift 114: 108-117.

Hannukkala, A. 1985. Inverkan av ensidig spannmálsod- ling på stråbassjukdomar. Văxtskyddsnotiser 49: 75-78. - 1988. Vehnän ja ohran tyvi- ja juuristotaudit eri viljelyjärjestelmissä. Licentiate dissertation. 94 p. Helsinki.

Harman, G. E. \& Taylor, A. G. 1990. Development of an effective biological seed treatment system. In: Hornby, D. (ed.). Biological control of soil-borne plant pathogens. Wallingford, Oxon. C. A. B. International. p. 415-426.

Kurppa, A. 1985. The pathogenicity and importance of seed-borne infection by Bipolaris sorokiniana on barley in Finland. Journal of Agricultural Science in Finland 57: 107-115.

Lahdenperä, M-L. 1987. The control of Fusarium wilt on carnation with Streptomyces preparation. Acta Horticulturae 216: 85-92.

- 1992. Biological control of Gerbera wilt on rockwool. Bulletin OILB/SROP 15, 1: 124-126.

-, Simon, E. \& Uoti, J. 1992. Mycostop - a novel biofungicide based on Streptomyces bacteria. Proceedings of 


\section{AGRICULTURAL SCIENCE IN FINLAND}

Tahvonen $R$. et al.: Effect of seed dressing treatment of streptomyces griseoviridis...

the First Conference of the European Foundation for Plant Pathology. Developments in Agricultural and ManagetForest Ecology 23: 258-263.

Mäkelä, K. \& Parikka, P. 1980. Root and foot rot diseases of cereals in Southern Finland in 1975-78. Annales Agriculturae Fenniae 19: 223-253.

Mangenot, F. \& Diem, H. G. 1979. Fundamantals of biological control. In: Krupa, S. V. \& Dommerques, Y. R. (eds.). Ecology of root pathogens. Amsterdam, Oxford, New York, Elsevier Scientific Publishing Company. p. 207265.

Papavizas, G. C. \& Lewis, J. A. 1980. Introduction and augmentation of microbial antagonists for the control of soilborne pathogens. Beltsville Symposia in Agricultural Research (5). Biological control in crop production. London. p. 305-322.

Ryder, M. H., Brisbane, P. G. \& Rovira, A. D. 1990. Mechanisms in the biological control of take-all of wheat by rhizosphere bacteria. In: Hornby, D. (ed.). Biological control of soil-borne plant pathogens. Wallingfort, Oxon. C. A. B. International. p. 123-130.

Salt, G. A. 1979. The increasing interest in minor pathogens. In: Shippers, B. \& Gams, W. (eds.). Soil-borne plant pathogens. London, New York, San Francisco, Academic Press. p. 289-312.

Tahvonen, R. 1982. Preliminary experiments into the use of Streptomyces spp. isolated from peat in the biological control of soil and seed-borne diseases in peat culture. Journal of the Scientific Agricultural Society of Finland
54: 357-369.

- 1988. Microbial control of plant diseases with Streptomyces spp. EPPO Bulletin 18: 55-59.

- \& Avikainen, H. 1987. The biological control of seedborne Alternaria brassicicola of cruciferous plants with a powdery preparation of Streptomyces sp. Journal of Agricultural Science in Finland 59: 199-208.

- \& Avikainen, H. 1990. Effect of Streptomyces sp. on seed-borne foot rot diseases of wheat and barley. I. Pot experiments. Annales Agriculturae Fenniae 29: 187-194. Uoti, J. 1976. The effect of five Fusarium species on the growth and developement of spring wheat and barley. Annales Agriculturae Fenniae 15: 254-262.

- 1979. Study of control of seed-borne Fusarium in cereals. Annales Agriculturae Fenniae 18: 149-153.

Weller, D. M. \& Cook, R. J.1983. Suppression of takeall of wheat by seed treatments with fluorescent Pseudomonas. Phytopathology 73: 436-469.

Wiese, M. V. 1987. Compendium of wheat diseases. 2nd ed. St. Paul, Minnesota, American Phytopathological Society. $112 \mathrm{p}$.

Yarham, D. J. 1981. Practical aspects of epidemiology and control. In: Asher, M. J. C. \& Shipton, P. J. (eds.). Biology and control of take-all. London, New York, Toronto, Sydney and San Francisco, Academic Press. p. 353384.

Zadoks, J. C., Chang, T. T. \& Konzak, C. F. 1974. A decimal code for the growth stages of cereals. Weed Research 14: 415-421. 
Vol. 4: 419-427.

\title{
SELOSTUS
}

\section{Streptomyces griseoviridis siemenpeittauksen vaikutus ohraan ja kevätvehnään kenttäkokeissa}

\author{
Risto Tahvonen, Asko Hannukkala ja Hanna Avikainen \\ Maatalouden tutkimuskeskus
}

Streptomyces griseoviridis -sädesientä ja siitä tehtyä jauhemaista Mycostop-valmistetta testattiin vehnän ja ohran siemen- ja maalevintäisten tautien torjumiseksi. Siemenet kasteltiin mikrobin itiösuspensiolla tai ravistettiin mikrobijauheen kanssa peittauslaitteessa. Peittauksen tehoa selvitettiin luontaisesti ja keinotekoisesti saastutetuilla siemenillä ja erilaisissa esikasvikokeissa. Monipuolisessa kiertoviljelykokeessa oli esikasveina eri pituisia aikoja kaura, rypsi ja härkäpapu . Toisessa esikasvikokeessa oli esikasvina nurmi eri pituisia aikoja. Kokeet tehtiin vuosina 1982 1987 Viikissä, Kotkaniemessä, Mietoisissa ja Jokioisilla.

Monipuolisessa vuoroviljelykokeessa Streptomyces-peittaus lisäsi ohrasatoja, mutta vehnällä ei keskimäärin saatu sadonlisäyksiä. Vuosien väliset vaihtelut olivat suuria. Vuoroviljelykasvit lisäsivät vehnän satoa, mutta ohralla yksipuolinen viljely ei sanottavasti alentanut satoa suhteessa vuoroviljelyyn.
Nurmi ohran ja vehnän esikasvina alensi satoja, voimakkaammin vehnällä kuin ohralla. Siemenen peittaus lisäsi satoja varsinkin vehnällä, kun esikasvina oli ollut nurmi. Kemiallinen elohopeapeittausaine antoi suuremman sadonlisän kuin Streptomyces-peittaus. Parhaimmat sadonlisät olivat $860 \mathrm{~kg} / \mathrm{ha}$.

Siemenlevintäiset Fusarium- ja Bipolaris-sienet eivät vaikuttaneet ohran satoihin, jolloin peittauksillakaan ei saatu sadonlisiä. Vehnällä siemenen peittaus lisäsi satoja, kun siemen oli luontaisesti Fusariumsienten saastuttamaa. Kemiallinen elohopeapeittaus antoi paremman tuloksen kuin biologinen peittaus.

Tehdyt kokeet osoittivat, että biologisella Streptomyces-peittauksella voidaan saada sadonlisäyksiä, mutta kemiallisella peittauksella tulos on pelto-oloissa aina parempi. Tämän takia pelto-oloja varten tarvitaankin tehokkaampia antagonisteja, jos viljan viljelyssä halutaan käyttää biologista torjuntaa. 